University of Nebraska - Lincoln

DigitalCommons@University of Nebraska - Lincoln

Papers in the Earth and Atmospheric Sciences

Earth and Atmospheric Sciences, Department

8-2006

\title{
Cold climate in the eastern Australian mid to late Permian may reflect cold upwelling waters
}

Andrew T. Jones

Geoscience Australia, Canberra

Tracy D. Frank

University of Nebraska-Lincoln, tfrank2@unl.edu

Christopher R. Fielding

University of Nebraska-Lincoln, cfielding2@unl.edu

Follow this and additional works at: https://digitalcommons.unl.edu/geosciencefacpub

Part of the Earth Sciences Commons

Jones, Andrew T.; Frank, Tracy D.; and Fielding, Christopher R., "Cold climate in the eastern Australian mid to late Permian may reflect cold upwelling waters" (2006). Papers in the Earth and Atmospheric Sciences. 112.

https://digitalcommons.unl.edu/geosciencefacpub/112

This Article is brought to you for free and open access by the Earth and Atmospheric Sciences, Department of at DigitalCommons@University of Nebraska - Lincoln. It has been accepted for inclusion in Papers in the Earth and Atmospheric Sciences by an authorized administrator of DigitalCommons@University of Nebraska - Lincoln. 
Published in Palaeogeography, Palaeoclimatology, Palaeoecology 237:2-4 (August 4, 2006), pp. 370-377;

doi: 10.1016/j.palaeo.2005.12.009 Copyright (C) 2005 Elsevier B. V.

Used by permission. http://www.elsevier.com/locate/palaeo

Submitted July 20, 2005; revised December 9, 2005; accepted December 13, 2005; published online February 9, 2006.

\title{
Cold climate in the eastern Australian mid to late Permian may reflect cold upwelling waters
}

\author{
Andrew T. Jones, ${ }^{1}$ Tracy D. Frank, ${ }^{2}$ and Christopher R. Fielding ${ }^{2}$ \\ ${ }^{1}$ Geoscience Australia, GPO Box 378, Canberra, ACT, 2601, Australia \\ ${ }^{2}$ Department of Geosciences, 214 Bessey Hall, University of Nebraska-Lincoln, \\ Lincoln, Nebraska 68588-0340, USA; email tfrank2@unl.edu \& cfielding2@unl.edu \\ Corresponding author - A. T. Jones, tel 612 6249 9768, fax 612 6249 9980, email Andrew.Jones@ga.gov.au
}

\begin{abstract}
A suite of ice-rafted dropstones and glendonites throughout the Permian succession of eastern Australia indicates the cold climate associated with the late Paleozoic ice age persisted longest in this part of Gondwana. Paradoxically, these cold climate indicators are preserved in transgressive and highstand facies and formed at mid to high latitudes at a time when paleofloral and sedimentological data suggest equable onshore environments during the intervening lowstands and temperate conditions at the pole. These apparent inconsistencies suggest that eastern Australia was anomalously cold in the context of post-Sakmarian Gondwanan climates, and the distribution of sedimentary indicators could indicate localized cooling by oceanographic processes. Modern upwelling of cold abyssal waters produces the specific physiochemical conditions necessary for ikaite formation, and is likely to have contributed to the development of glendonites in the eastern Australian Permian system. Such upwelling would have locally lowered surface water temperatures such that seasonal sea or river ice could form, which rafted debris across the marine shelf, and a cold-water fauna could develop. This hypothesis is supported by coupled atmosphere-ocean models for the Permian, which suggest that wind systems may have driven upwelling along this section of the Gondwanan coast. Colder conditions dissipated with the onset of the Hunter-Bowen Contractional Event and the transformation of the basin system from an open marine shelf to a foreland basin. This new hypothesis reconciles the prolonged deposition of cold-climate indicators in the eastern Australian Permian with an apparent post-Sakmarian warming elsewhere in Gondwana.
\end{abstract}

Keywords: Permian, Gondwana, Eastern Australia, late Paleozoic ice age, cold climate indicators, paleoclimate models, upwelling

\section{Introduction}

A record of the late Paleozoic ice age is widely distributed in the sedimentary basins of Gondwana. The youngest evidence of a cold climate in Gondwana occurs in the Permian of eastern Australia (Figure 1), in the form of outsized clasts interpreted as ice-rafted debris (IRD) and glendonites, pseudomorphs after ikaite. Based on such evidence, previous workers have sug- gested that ice age conditions in eastern Australia persisted into the Late Permian (e.g. Veevers and Powell, 1987; Crowell, 1995). Recent models that suggest the ice age terminated synchronously in the mid-Sakmarian (Dickins, 1996; Isbell et al., 2003) do not account for the presence of cold climate indicators in late SakmarianWordian strata of eastern Australia.

The distribution of cold climate indicators within the eastern Australian Permian succession is somewhat par- 


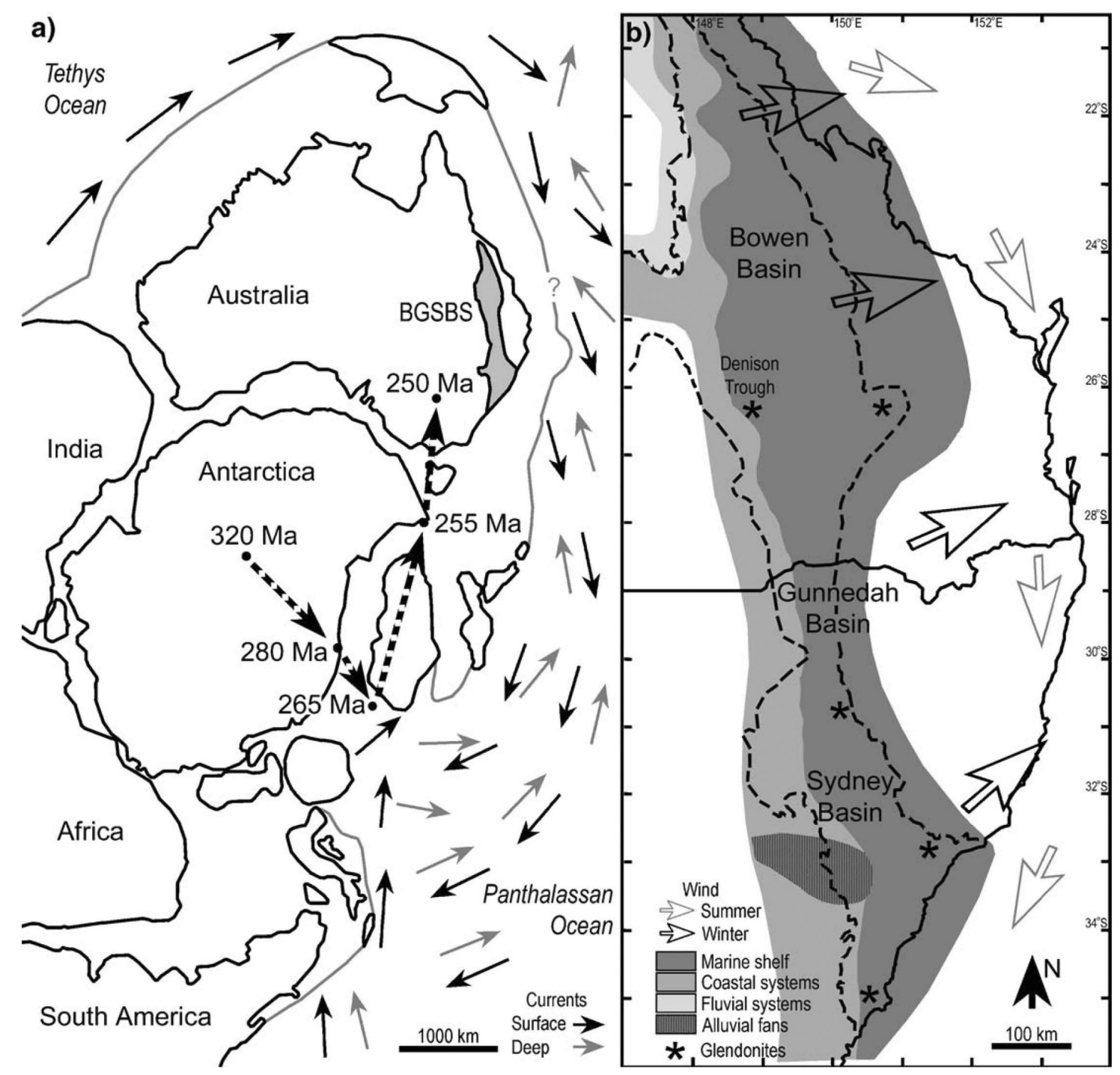

Figure 1. (a) Position of eastern Australia in Gondwana during the Permian, with surface and deep currents (Winguth et al., 2002) and apparent polar wander path indicated by dashed line (Powell and Li, 1994). (b) Paleogeography of the Bowen-GunnedahSydney Basin System during the mid-Permian (Fielding et al., 2001), including prevailing winds (Gibbs et al., 2002) and locations of glendonite discoveries (stars).

adoxical in the context of the enclosing facies. The lowstand/highstand cyclicity of the Bowen-GunnedahSydney Basin System (BGSBS) is inter-regional and of a scale suggestive of glacial/interglacial control (Figure 2; Veevers and Powell, 1987). However, cold climate indicators (glendonites and IRD) in these basins are preferentially distributed in highstand marine mudrocks, normally associated with warm interglacial periods, whereas many of the sandstone-dominated, lowstand units preserve substantial coal deposits. A further complication is highlighted in comparing the Permian successions from eastern and Western Australia. Despite similar basin fills and paleolatitudinal positions coldclimate indicators in the post-Sakmarian succession of Western Australia are conspicuously absent, with no glendonites discovered to date (Gorter, 2002) and "dropstones" reinterpreted in some cases as components of gravity flows (Eyles and Eyles, 2000).

This paper proposes an oceanographic explanation for the persistence of cold climate in eastern Australia subsequent to the termination of glacial conditions elsewhere in Gondwana, whereby upwelling waters along the eastern margin of Gondwana maintained cold sea floor conditions through to Wordian time.

\section{Geologic setting}

The BGSBS (Figure 1) formed along the Panthalassan margin of Gondwana in the Late Paleozoic, occupying 


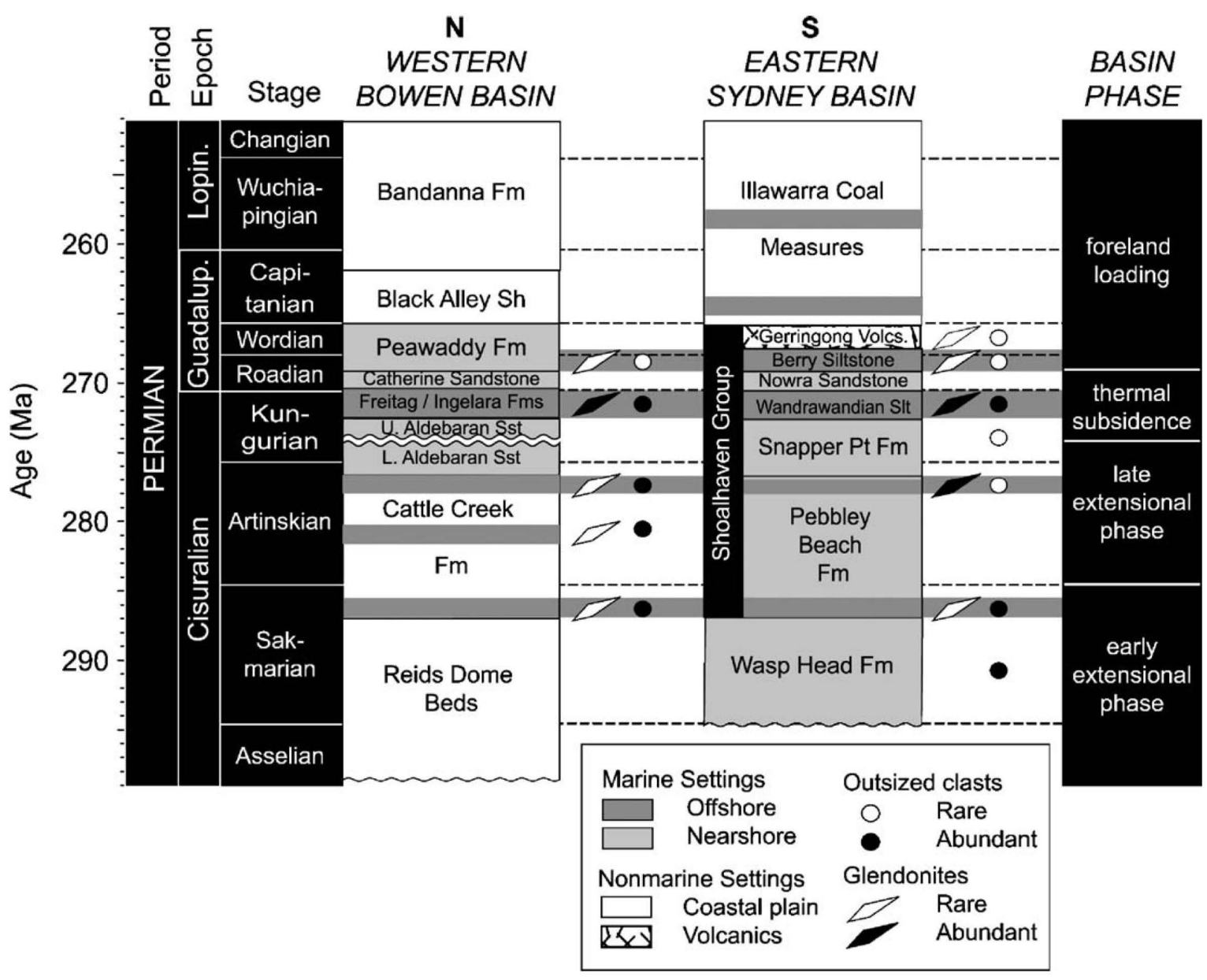

Figure 2. Representative stratigraphy of the Bowen-Gunnedah-Sydney Basin System from the western Bowen Basin (Denison Trough) and eastern Sydney Basin, showing the stratigraphic extent and preferential distribution of cold climate indicators in the highstand/transgressive facies. Also indicated are tectonic phases in basin evolution from Fielding et al. (2001). Timescale is that of Gradstein et al. (2004).

polar to temperate paleolatitudes (Powell and Li, 1994). Marine transgressions of inter-regional extent, and hence likely glacio-eustatic or glacio-isostatic in origin, periodically flooded the system during basin evolution (Fielding et al., 2001). Highstand facies are characterized by fine-grained offshore transition to shelfal deposits, and lowstand facies are predominantly sandy shoreface and deltaic deposits with coal measures common in the Late Permian (Figure 2).

Glacial facies have not been definitively identified in the Permian of the BGSBS. Units in the Sydney and Gunnedah Basins that have previously been characterized as glacial in nature have been subsequently reinterpreted as high-energy braidplain deposits or transgressive fan delta complexes (Tadros, 1993 and Tye et al., 1996). Glacial interpretations in post-Sakmarian strata of the Bowen Basin have been tentative at best, and recent work suggests that glaciers did not directly influence sedimentation in this part of eastern Australia (Jones and Fielding, 2004).

\section{Cold climate indicators in the BGSBS}

\subsection{Outsized clasts}

Outsized clasts are preserved throughout the Sakmarian-Wordian succession in the BGSBS (Figure 2). The lonestones, which range from gravel to boulder (up to $3 \mathrm{~m}$ in diameter; Figure 3) size, are preserved predominantly in fine-grained offshore facies, although they also occur in coastal facies and lacustrine units. The abundance of lonestones, interpreted as IRD, varies from isolated clasts to clast layers over $1 \mathrm{~m}$ thick. A number of the lonestones penetrate and depress underlying sediments, suggestive of impact structures, and are draped by overlying sediments. The clasts are polymictic, and vary widely in shape and roundness. The main lithologies are sedimentary (sandstone, minor limestone), lowgrade metasedimentary (phyllite, quartzite, chert), felsic volcanic and intrusive, and vein quartz, which together account for $>95 \%$ of total clasts found. Orientation of 


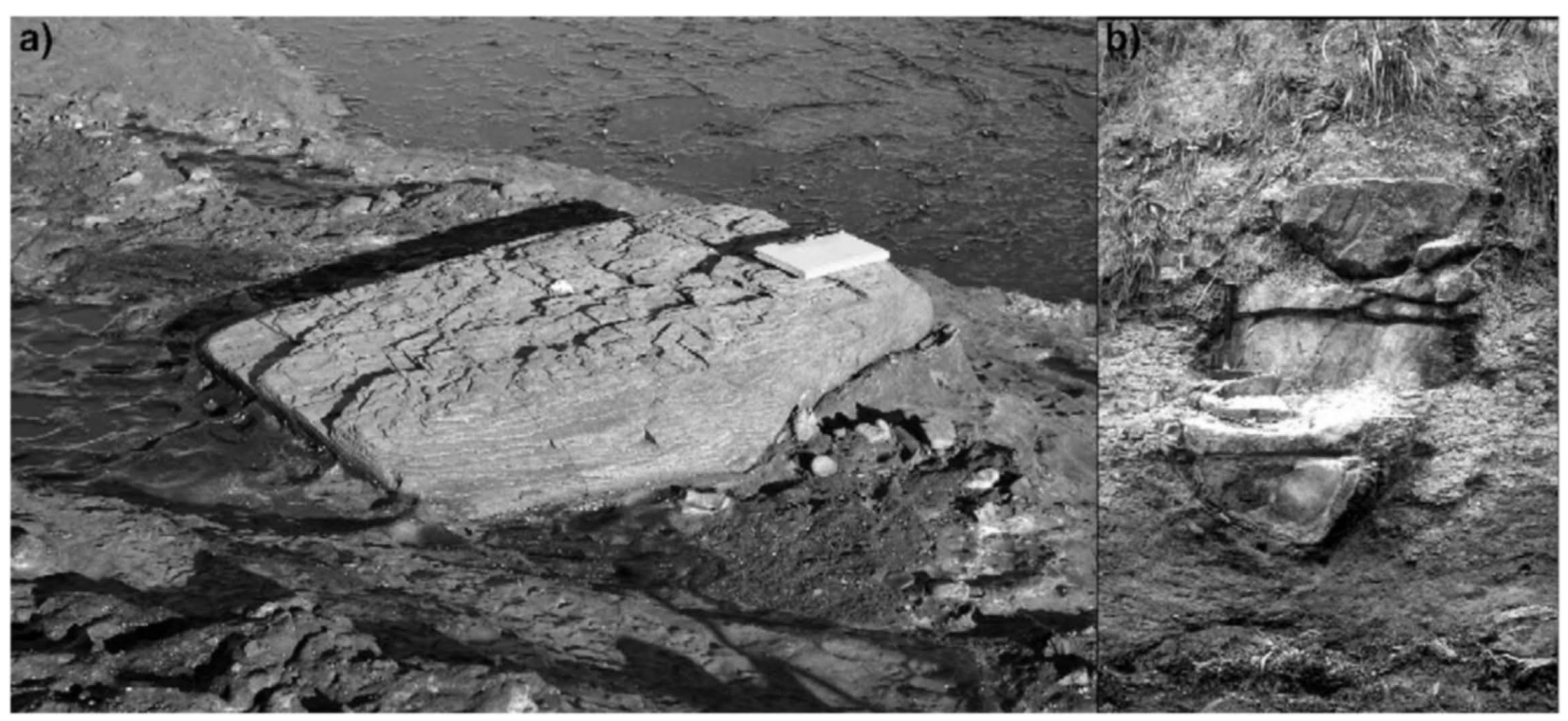

Figure 3. (a) Metasedimentary lonestone from the basal Pebbley Beach Formation at Depot Beach, NSW (UTM zone 56H, 0257700, 6055200). Book is $190 \mathrm{~mm}$ long. (b) Dropstone in the type section of the Cattle Creek Formation, southwestern Bowen Basin (UTM zone 55J, 0631400, 7247600). Hammer is $250 \mathrm{~mm}$ long.

the clasts within individual layers tends to be random. A small number of the lonestones were found to preserve striations. For detailed descriptions of clast distributions see Crowell and Frakes (1971), Draper (1983), and Eyles et al. (1997).

The abundance and size of the clasts, the drop, dump and rarely grounding structures (cf. Thomas and Connell, 1985) within which they are preserved, and to a lesser extent the random fabrics shown by the more elongate clasts, indicate that outsized clasts of the BGSBS were rafted into the marine environment by floating ice. Crowell and Frakes (1971) and Eyles et al. (1997) asserted that outsized clasts in the southern Sydney Basin were exotic, and invoked iceberg drifting from Antarctica as the likely mechanism of introduction to that area. However, Tye et al. (1996) found that the lithology of clasts corresponded closely to that of the Lachlan Fold Belt basement in the immediate hinterland, and proposed that clasts were more likely locally derived and delivered mainly via river-borne ice. In the Bowen Basin, a decrease in abundance of clasts away from the southwestern basin margin and the predominance of rounded spherical forms were interpreted by Draper (1983) to indicate rafting from local river or beach sources by seasonal ice (see also Jones, 2003). In both the Sydney and Bowen Basins, the widespread extent of outsized debris argues against a direct glacial origin (cf. Anderson et al., 1980). Sea ice in combination with icebergs can readily account for the distribution of outsized material in the BGSBS (cf. Thomas and Connell, 1985; Kempema et al., 1989).

\subsection{Glendonites}

On the basis of morphology and crystal habit, glendonites in Permian strata of eastern Australia (Figure 4) are interpreted as pseudomorphs after ikaite, the hexahydrate of $\mathrm{CaCO}_{3}$ (for a review see Carr et al., 1989).

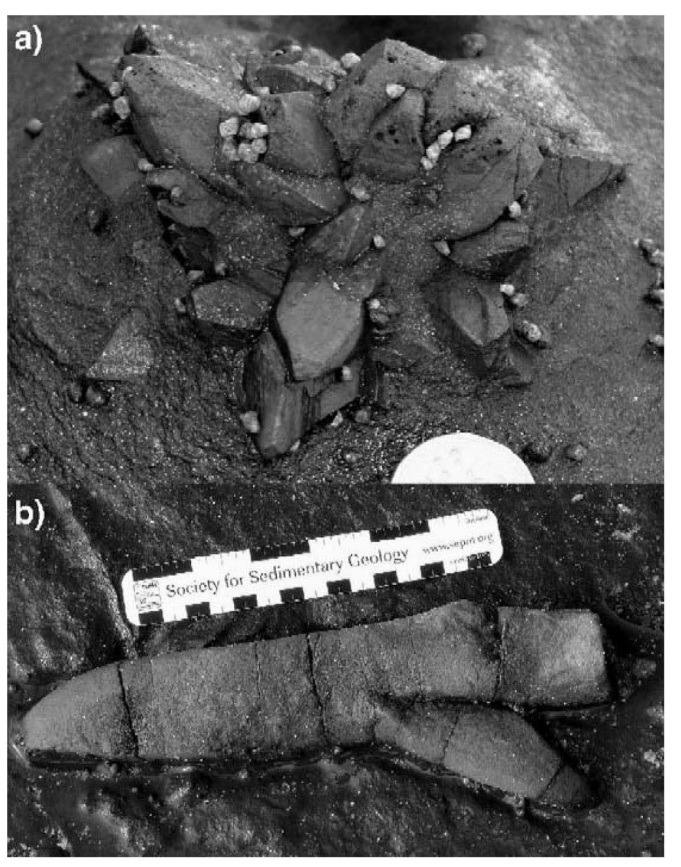

Figure 4. Glendonites from the Wandrawandian Siltstone in the southeast Sydney Basin, with rosette (a; coin is $25 \mathrm{~mm}$ across) and bladed (b; upper scale - in., lower scale $-\mathrm{cm}$ ) morphologies (UTM zone 56H, 0271350, 6084900). 
The pseudomorphs are abundant throughout the geographic extent of the BGSBS and in units of Sakmarian through Wordian age (Figure 2; Dickins, 1996). The most common lithologic association for glendonites is finegrained, dark gray (organic-rich) mudstones and sandy mudstones with scattered outsized clasts, interpreted as offshore to offshore-transition facies.

The association of glendonites with cold conditions stems from the physiochemical requirements for ikaite precipitation, namely low temperatures $(-1.9$ to +7 $\left.{ }^{\circ} \mathrm{C}\right)$, high alkalinity, and elevated concentrations of orthophosphate (Suess et al., 1982; Bischoff et al., 1993). Upon exposure to higher temperatures, ikaite becomes unstable and transforms to calcite. In modern settings, ikaite has been discovered growing displacively within organic-rich, terrigenous mud on high-latitude shelves (Suess et al., 1982; Kodina et al., 2003; Greinert and Derkachev, 2004). In the Kara Sea, where bottom temperatures are $-1.5^{\circ} \mathrm{C}$, pore water geochemical profiles indicate that ikaite forms in zones of microbially mediated organic matter mineralization and sulfate reduction, which generates alkalinity (Kodina et al., 2003). In these sediments, ikaite carbonate and dissolved inorganic carbon (DIC) in surrounding pore waters have nearly identical $\delta^{13} \mathrm{C}$ values (as low as $-42 \%$ relative to the Vienna Peedee belemnite [VPDB] isotope standard), suggesting that the main source of carbon for ikaite precipitation is organic matter.

Glendonites of the Wandrawandian Siltstone of the Sydney Basin (Figure 4) are characterized by their large size, reaching up to $40 \mathrm{~cm}$ in length, and high abundance. Within this formation, they occur within dozens of discrete stratigraphic horizons with a spatial density, as determined from bedding plane exposures, of 5-25 specimens per $\mathrm{m}^{2}$. Petrographic examination of the glendonites by Thomas (2005) revealed a complex paragenesis, with up to six petrographic phases identified. The earliest formed phase has a morphology identical to the gross morphology of glendonites observed at the outcrop scale (e.g. Figure 4). Isotopic analysis of several glendonite specimens showed that the earliest formed phase is characterized by the lowest $\delta^{13} \mathrm{C}(-14 \%$ to $-28 \%$ VPDB $)$ and the highest $\delta^{18} \mathrm{O}(0$ to $-5 \%$ o values (Thomas, 2005). Whereas oxygen isotope compositions are consistent with precipitation (or transformation from ikaite to calcite) at low temperatures, the $\delta^{13} \mathrm{C}$ values suggest a substantial contribution of carbon from organic matter diagenesis. These data suggest that these Permian glendonites formed under conditions similar to those observed by Kodina et al. (2003), where ikaite is forming in the Kara Sea.

\subsection{Faunal assemblages}

The Early Permian marine environment of eastern Australia was dominated by the cold-resistant Eurydesma fauna (Dickins, 1978). The thick-shelled bivalve Eurydesma was an immobile, epifaunal suspension feeder that thrived in high productivity areas where organic detritus was abundant (Runnegar, 1979). The Eurydesma fauna, which includes other bivalves (e.g. Deltopecten), gastropods (e.g. Keenia) and brachiopods (e.g. Trigonotreta) associated with cold water, in addition to massive bryozoans (e.g. Stenopora) and tabulate corals (e.g. Cladochonus), is characterized by low diversity and very high population numbers (Dickins, 1978; Runnegar, 1979). This fauna was, however, succeeded by others of higher diversity during the later Early Permian.

\section{Discussion}

The Permian succession of eastern Australia, in which marine highstand facies containing cold climate indicators alternate with lowstand deposits that in some cases record forested peat swamps (Fielding et al., 2001), presents an intriguing paradox in the context of Gondwanan climates. Sedimentary and paleobotanical records for the post-Sakmarian Permian suggest that climate conditions at the pole were relatively mild (Rees et al., 2002), and sedimentary systems at paleolatitudes similar to those of eastern Australia (e.g. Western Australia) do not preserve a record of cold climate (Gorter, 2002). Therefore, eastern Australia appears to have been anomalously cold relative to the latitudinal temperature gradient for the time. As such, recent analogies such as the Quaternary of the high Arctic, in which sea-ice dominated glacial intervals are intercalated with low-stand progradational packages including coal seams (Hubberten et al., 2004), are not directly applicable to the analysis of BGSBS climate. One approach to resolving this paradox lies in accounting for the development of conditions necessary for ikaite formation, as recorded by the presence of abundant glendonites.

Studies of ikaite occurrences in slope settings of the Sea of Okhotsk (Greinert and Derkachev, 2004) and the Kara Sea (Kodina et al., 2003) off Siberia suggest that ikaite forms in settings where microbially mediated organic matter degradation is occurring and/or near cold hydrocarbon seeps, where upward-migrating, methane-rich fluids promote the anaerobic decomposition of organic matter. The absence of fossil gas-chimneys and chemosynthetic communities typically associated 
with methane vents (e.g. Greinert and Derkachev, 2004), however, suggests that cold methane seeps did not affect the shelf settings recorded in the Permian of eastern Australia.

Domack et al. (1993) interpreted organic-rich mudrocks with dropstones and glendonites in the Permian Tasmania Basin as recording phases of high productivity associated with physical stability of the photic zone through sea ice cover. Application of this model to the regional distribution of glendonites in the BGSBS would require almost complete coverage of the basin, which encompasses a broad, polar to temperate latitudinal span, with sea ice. In the BGSBS, upwelling is a process that could have led to the development of conditions favorable to ikaite formation, namely elevated productivity and increased organic matter transport, the development of anaerobic conditions below the sediment-water interface, and cold sea floor temperatures.

Upwelling of cold, nutrient-rich deep ocean water, by stimulating biological productivity in the shallow ocean, can lead to enhanced burial preservation of organic matter as the decomposition of sinking organic matter increases oxygen demand in the water column (Canfield, 1994). Along modern upwelling margins, shelf sediments have high total organic carbon (TOC) contents (Peru margin: up to 6 wt.\% TOC; Froelich et al., 1988; Benguela upwelling system: $2.5 \mathrm{wt} \%$ TOC average in Holocene shelf sediments, higher in Last Glacial Maximum sediments; Mollenhauer et al., 2002). The TOC contents in offshore Permian strata of eastern Australia are consistent with those that characterize modern sites of upwelling. For example, the Ingelara Formation (Bowen Basin) and the Wandrawandian and Mulbring (Berry Siltstone equivalent) siltstones of the Sydney Basin are characterized by TOC concentrations that approach, and in some cases exceed, $2 \mathrm{wt} . \%$ (Jackson et al., 1980; Stewart and Alder, 1995; Thomas, 2005). On the modern Peru continental margin, the upper $10 \mathrm{~cm}$ of the sediment profile is a zone of mixed suboxic to anoxic diagenesis, with high alkalinity and dissolved phosphate concentrations from 20 to $100 \mu \mathrm{M}$, orders of magnitude higher than overlying water column concentrations (Froelich et al., 1988). Assuming that similar diagenetic conditions developed within offshore muds of eastern Australia during Permian time, the upwelling of near-freezing deep water along this high latitude margin could have provided the final ingredient necessary for ikaite formation, namely cold bottom temperatures. In the Wandrawandian Siltstone, total organic carbon (TOC) and total nitrogen (TN) concentrations determined by Thomas (2005) are consistent with an upwelling scenario. The $\mathrm{C}: \mathrm{N}$ ra- tio in these sediments ranges from $\sim 3$ to 11 , suggesting that organic matter in these glendonite-bearing strata is largely of marine origin.

Reconstructions of Permian surface wind and ocean circulation patterns are consistent with the proposed upwelling scenario (Gibbs et al., 2002; Winguth et al., 2002). Such models predict westerly trade winds during the winter months, which may have pushed surface waters offshore, leading to the replacement of warm surface waters with cold abyssal waters that upwelled from the adjacent ocean basin. Upwelling could have continued during the summer, as southerly directed winds along the eastern Gondwanan coast generated an Ekman current that directed surface waters away from Gondwana and into the Panthalassan Ocean (Figure 1). Reconstructions of thermohaline circulation patterns suggest that cold, dense surface water sank at the southern pole and formed a deep water mass that flowed as a western boundary current along the eastern coast of Gondwana and toward equatorial regions (Figure 1; Winguth et al., 2002). Assuming that deep-water production was most intense during the winter months (Winguth et al., 2002) suggests that upwelling waters derived from this water mass would have been particularly cold.

In addition to generating conditions favorable for ikaite formation on the shelf, upwelling of cold oceanic deep water could have caused localized cooling along eastern Gondwana. Wind induced coastal upwelling along the New Jersey $\left(39^{\circ}\right.$ to $\left.40^{\circ} \mathrm{N}\right)$ and central Chilean $\left(36^{\circ}\right.$ to $\left.40^{\circ} \mathrm{S}\right)$ coasts reduces sea surface temperatures by $5^{\circ}$ to $7^{\circ} \mathrm{C}$ (Glenn et al., 1996; Atkinson et al., 2002). A similar reduction in surface temperatures along the eastern Australian margin would place the coastal environment within a temperature window compatible with the development of seasonal ice that could have carried outsized clasts out over the shelf.

Cold conditions along the eastern coast of Australia during the Permian due to upwelling could account for the absence of cold climate indicators in Western Australian strata of the same age, which has been a source of uncertainty given the similar basin fills and paleolatitudinal positions of the two regions (Gorter, 2002). Modeled winds and currents along the Western Australian coast would have prevented upwelling along the Tethyan margin. Moreover, paleoclimate models suggest that deep waters affecting this region originated at equatorial latitudes of the Tethys where estimated sea surface temperatures ranged from 12 to $24^{\circ} \mathrm{C}$ (Winguth et al., 2002). Even if upwelling did occur, model results suggest that sea floor temperatures would have been too high to have provided ideal conditions for glendonite formation. A lack of cold upwelling waters along the 
Western Australian coast could also explain the earlier extinction of the Eurydesma fauna in western relative to eastern Australia (cf. Dickins, 1978). In the Permian succession of eastern Australia, cold climate indicators are absent in post-Wordian strata. Their disappearance coincides with a change in the BGSBS from extension and thermal subsidence to foreland loading, which involved uplift to the east of what was previously a broad, open marine shelf (Fielding et al., 2001). We speculate that with the subsequent change in margin morphology, the influence of upwelling on climate conditions along the eastern Gondwanan margin diminished.

\section{Conclusions}

This upwelling hypothesis provides, for the first time, an explanation for the prolonged cold climate that led to the deposition of IRD and glendonites in the BGSBS subsequent to the apparent termination of the late $\mathrm{Pa}$ leozoic glaciation in the mid-Sakmarian, and is consistent with the evidence preserved in the sedimentary record and paleoclimate models for the time. Upwelling could account for the restriction of glendonites and IRD to eastern Australia, as paleoclimate model results suggest that Tethys sea floor temperatures would have been too high to have provided ideal conditions for glendonite formation in western regions (Winguth et al., 2002). It may also account for the presence of glendonites and dropstones in strata of other ages (e.g. Early Cretaceous) for which direct evidence for glaciation is otherwise lacking. Testing of this model will require further examination of isotopic and geochemical data within well-defined sedimentological and stratigraphic frameworks.

\section{Acknowledgments}

We would like to thank F. Surlyk and two anonymous reviewers for Palaeogeography, Palaeoclimatology, Palaeoecology, for their comments on the manuscript. We also wish to thank the individuals who read a previous version of the manuscript, and greatly improved it through their input. CRF and TDF are supported by NSF Grant EAR-0417578. ATJ publishes with the permission of the Chief Executive Officer, Geoscience Australia.

\section{References}

Anderson et al., 1980 - J. B. Anderson, D. D. Kurtz, E. W. Domack, and K. M. Balshaw, Glacial and glacial marine sediments of the Antarctic continental shelf, Journal of Geology 88 (1980), pp. 399-414.
Atkinson et al., 2002 • L. P. Atkinson, A. Valle-Levinson, D. Figueroa, R. De Pol-Holz, V. A. Gallardo, W. Schneider, J. L. Blanco, and M. Schmidt, Oceanographic observations in Chilean coastal waters between Valdivia and Concepción, Journal of Geophysical Research 107 (2002).

Bischoff et al., 1993 - J. L. Bischoff, J. A. Fitzpatrick, and R. J. Rosenbauer, The solubility and stabilization of ikaite $\left(\mathrm{CaCO}_{3}{ }^{*} 6 \mathrm{H}_{2} \mathrm{O}\right)$ from $0^{\circ}$ to $25^{\circ} \mathrm{C}$ : Environmental and paleoclimatic implications for thinolite tufa, Journal of Geology 101 (1993), pp. 21-33.

Canfield, 1994 - D. E. Canfield, Factors influencing organic carbon preservation in marine sediments, Chemical Geology 114 (1994), pp. 315-329.

Carr et al., 1989 - P. F. Carr, B. G. Jones, and R. G. Middleton, Precursor and formation of glendonites in the Sydney Basin, Australian Mineralogist 4 (1989), pp. 3-12.

Crowell, 1995 - J. C. Crowell, The ending of the Late Paleozoic Ice Age during the Permian Period. In: P. A. Scholle, T. M. Peryt and D. S. Ulmer-Scholle, eds., The Permian of Northern Pangea, Springer-Verlag, New York (1995), pp. 62-74.

Crowell and Frakes, 1971 - J. C. Crowell and L. A. Frakes, Late Palaeozoic glaciation of Australia, Journal of the Geological Society of Australia 17 (1971), pp. 115-155.

Dickins, 1978 - J. M. Dickins, Climate of the Permian in Australia: The invertebrate faunas, Palaeogeography, Palaeoclimatology, Palaeoecology 23 (1978), pp. 33-46.

Dickins, 1996 - J. M. Dickins, Problems of a late Palaeozoic glaciation in Australia and subsequent climate in the Permian, Palaeogeography, Palaeoclimatology, Palaeoecology 125 (1996), pp. 185-197.

Domack et al., 1993 • E. W. Domack, L. A. Burkley, C. R. Domack, and M. R. Banks, Facies analysis of glacial pebbly mudstones in the Tasmania Basin: Implications for regional palaeoclimates during the late Palaeozoic. In: R. H. Findlay, R. Unrug, M. R. Banks, and J. J. Veevers, eds., Assembly, Evolution and Dispersal; Proceedings of the Gondwana Eight Symposium, International Gondwana Symposium vol. 8 (1993), pp. 471-484.

Draper, 1983 - J. J. Draper, Origin of pebbles in mudstones in the Denison Trough, Proceedings of the Symposium on Permian Geology of Queensland, Geological Society of Australia, Brisbane (1983), pp. 305-316.

Eyles and Eyles, 2000 - C. H. Eyles and N. Eyles, Subaqueous mass flow origin for Lower Permian diamictites and associated facies of the Grant Group, Barbwire Terrace, Canning Basin, western Australia, Sedimentology 47 (2000), pp. 343-356.

Eyles et al., 1997 • N. Eyles, C. H. Eyles, and V. A. Gostin, Iceberg rafting and scouring in the Early Permian Shoalhaven Group of New South Wales, Australia: Evidence of Heinrich-like events?, Palaeogeography, Palaeoclimatology, Palaeoecology 136 (1997), pp. 1-17.

Fielding et al., 2001 • C. R. Fielding, R. Sliwa, R. J. Holcombe, and A. T. Jones, A new palaeogeographic synthesis for the Bowen, Gunnedah and Sydney Basins of eastern Australia, Petroleum Exploration Society of Australia Eastern Australasian Basins Symposium, Melbourne (2001), pp. 269-279.

Froelich et al., 1988 • P. N. Froelich, M. A. Arthur, W. C. Burnett, M. Deakin, V. Hensley, R. Jahnke, L. Kaul, K.-H. Kim, K. Roe, A. Soutar, and C. Vathakanon, Early diagenesis 
or organic matter in Peru continental margin sediments: Phosphorite precipitation, Marine Geology 80 (1988), pp. 309-343.

Gibbs et al., 2002 - M. T. Gibbs, P. M. Rees, J. E. Kutzbach, A. M. Ziegler, P. J. Behling, and D. B. Rowley, Simulation of Permian climate and comparison with climate-sensitive sediments, Journal of Geology 110 (2002), pp. 33-55.

Glenn et al., 1996 - S. Glenn, M. Crowley, D. Haidvogel, and Y. T. Song, Underwater observatory captures coastal upwelling events off New Jersey, Eos Transactions of the American Geophysical Union 77 (1996), pp. 233-236.

Gorter, 2002 - J. Gorter, Why are there no glendonites in the western Australia Permian?, Petroleum Exploration Society of Australia News 55 (2002), p. 38.

Gradstein et al., 2004 • F. M. Gradstein, J. G. Ogg, A. G. Smith, F. P. Agterberg, W. Bleeker, R. A. Cooper, V. Davydov, P. Gibbard, L. Hinnov, M. R. House, L. Lourens, H.-P. Luterbacher, J. McArthur, M. J. Melchin, L. J. Robb, J. Shergold, M. Villeneuve, B. R. Wardlaw, J. Ali, H. Brinkhuis, F. J. Hilgen, J. Hooker, R. J. Howarth, A. H. Knoll, J. Laskar, S. Monechi, J. Powell, K. A. Plumb, I. Raffi, U. Röhl, A. Sanfilippo, B. Schmitz, N. J. Shackleton, G. A. Shields, H. Strauss, J. Van Dam, J. Veizer, Th. van Kolfschoten, and D. Wilson, A Geologic Timescale 2004, Cambridge University Press (2004) 500 pp. .

Greinert and Derkachev, $2004 \cdot J$. Greinert and A. Derkachev, Glendonites and methane-derived $\mathrm{Mg}$-calcites in the Sea of Okhotsk, eastern Siberia: Implications of a venting-related ikaite/glendonite formation, Marine Science 204 (2004), pp. 129-144.

Hubberten et al., $2004 \cdot$ H. W. Hubberten, A. Andreev, V. I. Astakhov, I. Demidov, J. A. Dowdeswell, M. Henriksen, C. Hjort, M. Houmark-Nielsen, M. Jakobsson, S. Kuzmina, E. Larsen, J. P. Lunkka, A. Lyså, J. Mangerud, P. Möller, M. Saarnisto, L. Schirrmeister, A. V. Sher, C. Siegert, M. J. Siegert, and J. I. Svendsen, The periglacial climate and environment in northern Eurasia during the Last Glaciation, Quaternary Science Reviews 23 (2004), pp. 1333-1357.

Isbell et al., 2003 - J. L. Isbell, M. F. Miller, K. L. Wolfe, and P. A. Lenaker, Timing of late Paleozoic glaciation in Gondwana: Was glaciation responsible for the development of northern hemisphere cyclothems? In: M. A. Chan and A. A. Archer, eds., Extreme Depositional Environments: Mega End Members in Geologic Time, Geological Society of America Special Paper vol. 370 (2003), pp. 5-24.

Jackson et al., 1980 - K. S. Jackson, P. J. Hawkins, and A. J. R. Bennett, Regional facies and geochemical evaluation of the southern Denison Trough, Queensland, The Australia Petroleum Exploration Association Journal 20 (1980), pp. 143-158.

Jones, 2003 - Jones, A. T., 2003. Sedimentological record of the late Palaeozoic glaciation in Queensland. Ph. D. Thesis, Department of Earth Sciences, The University of Queensland. 365 pp.

Jones and Fielding, $2004 \cdot$ A. T. Jones and C. R. Fielding, Sedimentological record of the late Paleozoic glaciation in Queensland, Australia, Geology 32 (2004), pp. 153-156.

Kempema et al., 1989 - E. W. Kempema, E. Reimnitz, and P. W. Barnes, Sea ice sediment entrainment and rafting in the Arctic, Journal of Sedimentary Petrology 59 (1989), pp. 308-317.
Kodina et al., 2003 - L. A. Kodina, V. G. Tokarev, L. N. Blasova, and G. S. Korobeinik, Contribution of biogenic methane to ikaite formation in the Kara Sea: Evidence from the stable isotope geochemistry. In: R. Stein, K. Fahl, D. K. Fuetterer, E. M. Galimov, and O. V. Stepanets, eds., Siberian River Run-Off in the Kara Sea, Elsevier (2003), pp. 349-374.

Mollenhauer et al., 2002 • G. Mollenhauer, R. R. Schneider, P. J. Müller, V. Speiss, and G. Wefer, Glacial/interglacial variability in the Benguela upwelling system: Spatial distribution and budgets of organic carbon accumulation, Global Biogeochemical Cycles 16 (2002), pp. 81-1-81-15.

Powell and Li, 1994 - C. McA. Powell and Z. X. Li, Reconstructions of the Panthalassan margin of Gondwanaland. In: J. J. Veevers and C. McA. Powell, eds., Permian-Triassic Pangean Basins and Foldbelts along the Panthalassan Margin of Gondwanaland, Geological Society of America Memoir, vol. 184 (1994), pp. 5-9.

Rees et al., 2002 - P. M. Rees, A. M. Ziegler, M. T. Gibbs, J. E. Kutzbach, P. J. Behling, and D. B. Rowley, Permian phytogeographic patterns and climate data-model comparisons, Journal of Geology 110 (2002), pp. 1-31.

Runnegar, 1979 - B. Runnegar, Ecology of Eurydesma and the Eurydesma fauna, Permian of eastern Australia, Alcheringa 3 (1979), pp. 261-285.

Stewart and Alder, 1995 - J. R. Stewart and J. D. Alder, eds., New South Wales Petroleum Potential, New South Wales Department of Mineral Resources, Sydney (1995) 188 pp.

Suess et al., 1982 • E. Suess, W. Balzer, K. F. Hesse, P. J. Muller, and G. Wefer, Calcium carbonate hexahydrate from organic-rich sediments of the Antarctic Shelf: Precursors of glendonites, Science 1216 (1982), pp. 1128-1131.

Tadros, 1993 - N. Z. Tadros, The Gunnedah Basin, New South Wales, Geological Survey of New South Wales Memoir Geology, vol. 12 (1993) 649 pp. .

Thomas, 2005 - Thomas, S. G., 2005. A study of the lithostratigraphy and glendonites of the Wandrawandian Siltstone: Keys to the depositional and early diagenetic environments. MS Thesis, Department of Geosciences, University of Nebraska-Lincoln. 40 pp.

Thomas and Connell, 1985 • G. S. P. Thomas and R. J. Connell, Iceberg drop, dump, and grounding structures from Pleistocene glacio-lacustrine sediments, Scotland, Journal of Sedimentary Petrology 55 (1985), pp. 243-249.

Tye et al., 1996 - S. C. Tye, C. R. Fielding, and B. G. Jones, Stratigraphy and sedimentology of the Permian Talaterang and Shoalhaven Groups in the southernmost Sydney Basin, New South Wales, Australian Journal of Earth Sciences 43 (1996), pp. 57-69.

Veevers and Powell, $1987 \bullet$ J. J. Veevers and C. McA. Powell, Late Paleozoic glacial episodes in Gondwanaland reflected in transgressive-regressive depositional sequences in Euramerica, Geological Society of America Bulletin 98 (1987), pp. 475-487.

Winguth et al., 2002 • A. M. E. Winguth, C. Heinze, J. E. Kutzbach, E. Maier-Reimer, U. Mikolajewicz, D. Rowley, A. Rees, and A. M. Ziegler, Simulated warm polar currents during the middle Permian, Paleoceanography 17 (2002), p. 1057. 